\title{
Islamic Aniconism: Making Sense of A Messy Literature
}

\author{
Ismail Ozgur Soganci
}

\begin{abstract}
:
"Postmodern" authors such as Virilio, Baudrillard, Barthes, and Zizek express interesting sensitivities toward images (and their inflation in today's media) which remind the quarrels in 8th century Byzantine Iconoclasm. Historically, Anatolia (Turkey), where Byzantine Empire stood once, has been a fertile ground for religious debates over the nature of images. My study starts with the thesis that "the lawfulness of painting" in Islam, as coined by Creswell, is an ignored issue in today's Turkish art classroom. Through philosophical hermeneutic analysis of 30 interviews with 10 middle-school students, the study unfolds student meanings regarding various Muslim attitudes toward 2-D figural representation. Philosophical hermeneutics is a form of textual analysis that incorporates dialogue through conversations and elicitation with regard to contexts and history. For example, linking the (once-asked) participant question, "Mom, why isn't there a picture of our prophet?" to the greater cultural and historical aspects of TurkishIslamic context is crucial in such hermeneutic approach. I problematize the muteness of the centralized national art education curriculum on the issue and offer instructional strategies that incorporate the issue into modern art education practice. The creation of polyphonic spaces for students to explore these conflicting and coinciding ideas is essential unless one considers art education in Turkey a top-down imposition of Western "iconography" alone.
\end{abstract}

Oleg Grabar (1973), a noted scholar of Islamic art history, uses the word "aniconic" to refer to the widespread attitude in the history of Muslim cultures toward all kinds of figural representation (p. 6). While "iconoclasm," the name of the era when Christian icons were destroyed in and around Byzantine Constantinople (Istanbul) in the $8^{\text {th }}$ century, focuses historically on the negative influences of the representations of the divine, "aniconism" widens the range of such focus and suggests not producing figural imagery of any kind in the first place. What I call "Islamic aniconism" in my ongoing doctoral research has been a subject of theological debate in the culture of Islam for more than a millennium and it still is.

Cagman and Tanindi (1986), two well-established Islamic art historians in Turkey and abroad, wrote, "It is, ..., a hopeless task to try to make a coherent sense of everything, or even most things, which have been said by 
Muslims about painting, not to mention the things non-Muslims have said. Nevertheless, people are trying" (p. 24, emphasis is mine).

The difficulties in the way of studying Islamic art have been mentioned frequently in related literature. Some authors, like Sir Thomas Arnold who wrote the first comprehensive text regarding the place of painting in the culture of Islam, even devoted whole chapters to such discussions (see Arnold, 1965, pp. 41-51).

Whether one calls it "difficult to study" or "a hopeless task," there is an alarming need for art educators to direct their gaze upon aniconism and its origins in the Muslim cultures. In the interviews I conducted in Turkey at a middle school last year, a 12-year-old girl told me that she had asked her mother the following question:

"Mom, why isn't there a picture of our prophet?"

I asked her what her mother's response had been. She said:

"I do not remember. If it had been satisfactory, I would."

Today art teachers in Turkey are schooled to follow a curriculum that does not even include the word aniconism or any other equivalent term. The curriculum is mute when it comes to the Islamic unease toward images, as if it wants to make sure that school will never address this little girl's question.

In this paper, I explore the kinds of literature I came across in my journey toward responding to that 12-year old student's question. My review yielded the following list that conveys various predispositions or approaches with which authors express their thoughts on Islamic art and aniconism. Here, you will also see some elements that make it difficult to come out with a comprehensive response to the questions regarding aniconism. While many authors seem to pursue the underlying ideas of the below titles, some tend to utilize a couple of them together. Please, consider these as not literary canons or established stances but my little categories to make sense of a broad almost infinite mess. I first give a simple definition of the approaches and exemplify them with quotations from famous text in an interdisciplinary manner. 
Orientalist approach: I use this term to refer to authors who were raised in western cultural spheres and who write about Islamic art and all related issues from a dominantly western point of view using various western criteria. At times imaginary richness in their paragraphs takes over scholarly evidence. Orientalism manifests itself most clearly in young Marx's statement which was quoted by Edward Said in his introduction to Orientalism: "They cannot represent themselves, they need to be represented."

\section{a- The orient: the magnificent other:}

"As a great intellectual art, an art of the mind as much as of the eye, the miniature would come to monopolize painting and would be accorded high status and considered cosa mentale [a mental act] by the Muslims long before painters of the Western Renaissance, such as Leonardo da Vinci and others long after his time, would come to protest against their art being relegated to the manual trades" (Papadopoulo, 1980, p. 83).

\section{b- The orient: the miserable other:}

"So many foreign and non-Arab races had become absorbed into the fold of Islam, so many barbarians such as Mongols and Turks had after their conversion taken rank among the most powerful of contemporary Mohammadan [sic] sovereigns" (Arnold, 1965, p. 32).

Creswell (1932), when summarizing the origins of aniconism in Islam, mentions a psychological basis for the hostility to painting among what he calls "primitive people": they believed that the maker of an image or a painting in some way transfers part of the personality of the subject to the image or painting, and in so doing acquires magical powers over the person reproduced (p. 165).

2- Compare/contrast approach: This approach, mostly adopted by Muslim scholars who have been educated in western institutions, considers the incompatibility between eastern and western concepts of art as a problem to be solved. In this approach it is assumed that there is one uniform path humans have to follow. Variety, for them, is a result of wrongdoings either in the east or the west. They tend to compare and contrast eastern and western concepts of art in a onedimensional linear mindset. In many respects, they appear to be just like orientalists in their meaning-making processes. 


\section{a- The West: The magnificent other:}

"When Leonardo finished Mona Lisa in three years between 1503 and $1506, \ldots$ the then-ruling Ottoman sultan Bayazit II had already got rid of his father's portrait by the Italian painter Bellini, because he thought painting was a great sin" (Som, 2003, p. 7).

\section{b- The West: The miserable other:}

Al-Faruqi (1989) states that orientalists have exaggerated the place of figural paintings in the legacy of Islam (p. 266). He claims that, "this is due to their enthusiastic disposition toward figural representation which they prejudge as the most important form of aesthetic creativity" (AlFaruqi, 1989, p. 266). Unfortunately, having said that, he himself prejudges figural painting and writes, "Compared with the artworks of architecture, of the arabesque as transfiguring modality, of music, and of literature, the legacy of figural painting is of miserably less value" (AlFaruqi, 1989, p. 266).

3- Muslim Traditionalist approach: I use this term to refer to authors, who are generally religious Muslims, who base almost all their arguments on revelation and to the example set by Prophet Mohammed, who oppose utilization of thought on issues that have been brought to a conclusion by religious orthodoxy.

a- Those who favor strict prohibition of all images: They consider "the prohibition of images" as a main principle of Islam that had protected Muslims from pagan tendencies, and they see aniconism as a superior quality.

“... [E]ven if the thing represented is a tree, a mountain or a cloud, the artistic act is certainly one of defiance, nay of presumed supremacy of the artist over nature or God" (Al-Faruqi, 1989, p. 263).

b- Those who advocate the continuation of non-figural Islamic art and that tolerate secular figural representation: Authors in this approach tend to see Islamic art as only "religious art" and agree with the traditionalist argument in the first category regarding the conservation of non-figural artistic attitudes. They, on the other hand, unlike the ones in the first category, 
define a secular artistic sphere in which figural representation is permissible.

"Anyone who reviews the Koranic verses referring to idols and their worship will find that the prohibition is directed against worshipping idols and taking them as gods in the place of God. ...I have no doubt that representations and statues in themselves have nothing to do with the question of whether they are lawful or unlawful as debated by some jurisconsults" (Issa, 1977, p. 68).

4- Muslim Rationalist approach: This approach, with minor differences, argues for the indispensable nature of figural representation in today's world. They believe that the hadiths (traditions that are derived from Prophet Mohammed's life) regarding figural representation should be observed in context not as universal rules. They highlight the muteness of the Koran on the issue as the sole source for legislation in Islam. They do not hesitate to utilize rational thought processes to interpret revelation. They often quote Muslim and non-Muslim philosophers to support their claims.

"You cannot adduce the verdict that a representation, under all circumstances, is liable to be worshipped; for I think that one could say to you that your tongue also is liable to tell lies, but is it necessary to tie it up even though it may tell the truth as well as falsehood?" (Sheikh Mohammad Abduh cited in Issa, 1977, p. 62).

5- Nationalist approach: This term refers to the approach of authors who choose to remain distant to the umbrella term 'Islamic art' as their departure point in their writings. The emphasis is on the importance of racial and cultural orientations in the formation of artistic preferences. Some attribute the origins of aniconism to the temperamental dislike of images widespread in Semitic races, especially among Arabs. Instead of Islamic art, they would rather use Turkish art, Ottoman art, Persian art, etc.

Renda (1988) states that the Turkish pictorial art had its own specific line of development (p.16) before the Islamic period, and miniature painting was commonly practiced. She claims that Islamic traditions, interpreted during various periods "inhibited the development of representation of human likeness and, thus, the development of a monumental art of painting up until the nineteenth century" (Renda, 1988, p. 16). 
6- Philosophers and Contemporary theorists: Various philosophical approaches might be mentioned under this title. The authors in this category choose to theorize on human nature with regard to images in general. Their work contributes to studies on specific subjects such as mine as theoretical frameworks.

In our heavily iconic, mediated reality, we forget that our representations are copies (even copies of copies), and in turn they begin to seem "more real than the real." For Baudrillard, the postmodern condition thus becomes the "triumph of simulacra" (1988, p. 103). [Elsewhere, Baudrillard refers to simulacra as a referent without an original.]

“...[A]nd do we not find something similar in the new age cyberspace cult which attempts to ground the return of pagan wisdom in the highest technology?" (Zizek, 1997, p. 86).

"Thought long ago stopped assigning to art the sensible representation of the divine" (Hegel, translated from German by translated by T.M Knox, 1975).

7- Interdisciplinary (multiple perspectives) approach: The authors utilizing this approach scan literature from multiple disciplines such as history, art history, sociology, aesthetics, theology, philosophy, and so forth in order to construct a critical review that leads to more comprehensive texts. They often cover the issue of figural representation in a multiply but not overly determined way. A main characteristic I observed in such writings is that the texts do not lead the reader to an authoritative conclusion but rather to a polyphonic account to think about. In this approach, authors do not hesitate to share their cultural orientations, political stances, and ways of thinking with the reader.

"The presence of figural imagery, whether in architectural decoration, objects, or manuscript painting, was conspicuously downplayed in constructing the 'otherness' of the Arabo-Islamic visual tradition” (Necipoglu, 1995, p. 62).

\section{References}

Al-Alwani, T. J. (2000). Fatwa concerning the United States Supreme Court frieze. In Journal of Law and Religion, 15(1\&2), pp. 1-28. 
Al-Faruqi, I. (1989). Figurative representation and drama: Their prohibition and transfiguration in Islamic art. In Proceedings of the international symposium (Istanbul, 1984), Islamic art: Common principles, forms and themes. Damascus: Dar al-Fikr.

Arnold, T. W. (1965). Painting in Islam: a study of the place of pictorial art in Muslim culture. New York, NY: Dover.

Baudrillard, J. O. (1988). America. (Trans. C. Turner). New York, NY: Verso.

Cagman, F. \& Tanindi, Z. (1986). The Topkapi Saray Museum: the albums and illustrated manuscripts. (Trans. J. M. Rogers). New York' NY: Thames and Hudson.

Creswell, K. A. C. (2002). The lawfulness of painting in early Islam (Original article published in 1937). In Jonathan M. Bloom (Ed.), Early Islamic art and architecture (pp. 101-109) Burlington, VT: Ashgate.

Grabar, O. (1973). The formation of Islamic art. New Haven: Yale University Press.

Hegel, G. W. F. (1975). Aesthetics. (Trans. T. M. Knox). Oxford: Clarendon Press.

Issa, A. M. (1977). Painting in Islam: Between prohibition and aversion. Istanbul, TR.: Waqf for Research on Islamic History, Art and Culture.

Necipoglu, G. (1995). The Topkapi scroll: geometry and ornament in Islamic architecture. Santa Monica, CA: The Getty Center for the History of Art and Humanities.

Papadopoulo, A. (1980). Islam and Muslim art. (Trans. R. E. Wolf). London: Thames and Hudson. 
Renda, G.; Erol, T.; Turani, A.; Ozsezgin, K.; Aslier, M. (1988). A history of Turkish painting. Seatle: Palasar Sa \& University of Washington Press.

Said, E. W. (1978). Orientalism. New York, NY: Pantheon Books.

Som, D. (2003). Ronesans'ta Neredeydin? Istanbul, TR: Gunizi Yayincilik.

Zizek, S. (1997). The plague of fantasies. New York, NY: Verso. 